\title{
汎用化水田における水管理の変化が 魚類の生息に及ぼす影響とそのミティゲーションについて
}

\author{
森須美子 $^{1} \cdot$ 伊藤健吾 $^{2} \cdot$ 千家正照 $^{3}$
}

\author{
The Impact of the Change of Water Management by Improving Paddy Field \\ for Upland Crops Planting on Fish Habitat and its Mitigation Practices
}

\begin{abstract}
Sumiko Mori ${ }^{1}$, Kengo Ito $^{2}$ and Masateru Senge ${ }^{3}$
Abstract: In recent years, the drainage condition of rice fields has been improved for upland crops planting by the farm land consolidation in order to increase farm productivity. On the other hand, the improvement of drainage conditions in paddy field area greatly influenced the habitat of freshwater fishes. However, there are few researches on how freshwater fishes have been influenced by the drainage improvement. In this research, we investigated the difference between the environment for freshwater fishes in drainage canals in the year when the whole area was planted to rice and in the year when a part of the rice field area was planted to wheat. When an upland crop such as wheat was planted in paddy field area, the water depth in the drainage canal among all the environmental components greatly changed. The vegetation on the levees was not available for freshwater fishes due to the fact that the water level in the canal did not increase up to the level of levees, and this drastically decreased the number of fishes living in the canal. Furthermore, from the analysis of the relationship between the number of fishes and the distance from vegetation zone, it could be suggested that at least one vegetation zone of length $100 \mathrm{~m}$ must be created along the canal with the aim of maintaining the habitat for freshwater fishes.
\end{abstract}

Keywords: Multi-purpose paddy, Freshwater fish, Water depth, Vegetation zone

\section{1 はじめに}

近年, 水田の高度利用を目的として汎用化整備が進めら れ, 水田で烟作物の栽培が可能となり, 高い生産性が得ら れるようになった. このような沉用化水田は今後も増加して いくことが予想される. しかし, 水田に畑作物を導入するた めには, 暗渠を設置するなど圃場内の排水性を高めなけ ればならない. そのため, 汎用化水田における排水路は, 従来の圃場整備による排水路よりも暗渠出口を確保する ためにさらに染く掘り下げられ, 田面との落差が大きくなる だけではなく, 水田の乾田化が進むことになる(農林水産 省, 2004).さらに, 固場整備を実施する際に, 客土が行 われる場合が多く, 表土扱いなどの工法によって, 非作付 け期の畦畔や田面を利用して越冬する両生類への影響が 懸念される.また, 烟作物を作付けすることにより, 固場及 び水路などの水域が時間的にも空間的にも減少すること が挙げられる.

このように, 水田あるいは水田と連続する水路の環境が 変化すれば，そこに生息する生物に大きな影響が及ぶこ とは容易に推察できる.たとえば, 水田環境を代表する生

${ }^{1}$ 岐阜大学大学院連合農学研究科, Student, the United Graduate School of Agricultural Science, Gifu University, 1-1 Yanagido, Gifu-city, Gifu 501-1132, JAPAN

2 岐皁大学応用生物科学部准教授, Associate Professor, Faculty of Applied Biological Science, Gifu University, 1-1 Yanagido, Gifu-city, Gifu 501-1132, JAPAN

${ }^{3}$ 岐阜大学応用生物科学部教授, Professor, Faculty of Applied Biological Science, Gifu University, 1-1 Yanagido, Gifu-city, Gifu 501-1132, JAPAN (Corresponding Author) E-mail:senge@gifu-u.ac.jp
物のひとつであるメダカは, 平成 19 年の環境省の報道に よるレッドリストで絶滅危惧 I類に指定されるほど減少して いる. メダカが減少した原因の一つとして, 水田と水路の 間をメダカが自由に移動できなくなった環境があげられる (上月ら, 2000;小澤, 1999). 前述したように, 汎用化水田 では田面と水路の落差が増大寸るため, 物理環境はさら に悪化することが予想されるが, 汎用化された水田地帯で の物理環境の変化が, そこに生息する魚類に与える影響 について検証した例は少ない。

そこで本研究では, 水田の汎用化による生物への様々 な影響のうち, とくに畑作物の導入による水管理の変化が, 排水路内の環境亡魚類の生息状況にどのような影響を及 ぼすのかについて検討した. また，その結果をもとに生息 環境の保全方法についても検討を行った.

\section{2 調査の概要}

\section{1 調查地の概要}

調査地区の位置する岐阜県安八郡輪之内町は，揖斐川 と長良川に挟まれ周囲を堤防に囲まれた輪中地帯とな っており, 標高 $2.5 \mathrm{~m}$ 前後の低平地である. 輪中内は流 れの緩やかなクリーク状の水路が縦横に走り, 堀田と 呼ばれる特有の環境が残っていたことから，小型の淡 水魚をはじめとして多くの生物が生息していた.一方, 排水条件が悪く，圈場の区画が狭いなど営農には多大 な労力を要していたことから, 昭和 40 年代より固場整 備が順次行われてきた。 さらに，水田の汎用化を目的 に, 平成 16 年度から 21 年度までの工期で経営体育成 
基盤事業「輪之内本戸地区」が実施された。調査対象 としたのは，このような戋場整備が進行しつつあった 本戸地区（図 1 参照）を南北に走る 3 本の排水路（水 路 1〜3） と，各排水路が地区南部を東西に走る幹線排 水路と合流寸る 3 地点（11～(3)）の落口工，さらに， 平成 18 年度の冬期に水路 1 の上流部にビオトープの機 能を期待して人工的に設置した「池」（以下，「ビオト 一プ池」と称す）である。水稲灌泊期に排水路水位を 制御することを目的として，幹線排水路と水路 3 にそ れぞれ堰 $\mathrm{A}$ 及び堰 $\mathrm{B}$ が設けられている。 また，洪水時 に排水河川からの逆流を防ぐために，幹線排水路下流 端に堰 C が設置されている．調査対象施設の概要を表 1 に示す。なお, 調查対象地区の上流側 (北側) は輪 中堤によって遮断されているため，水路内に生息する 淡水魚は，水路内で繁殖したか，あるいは，下流の排 水河川から遡上してきた個体に限定される。

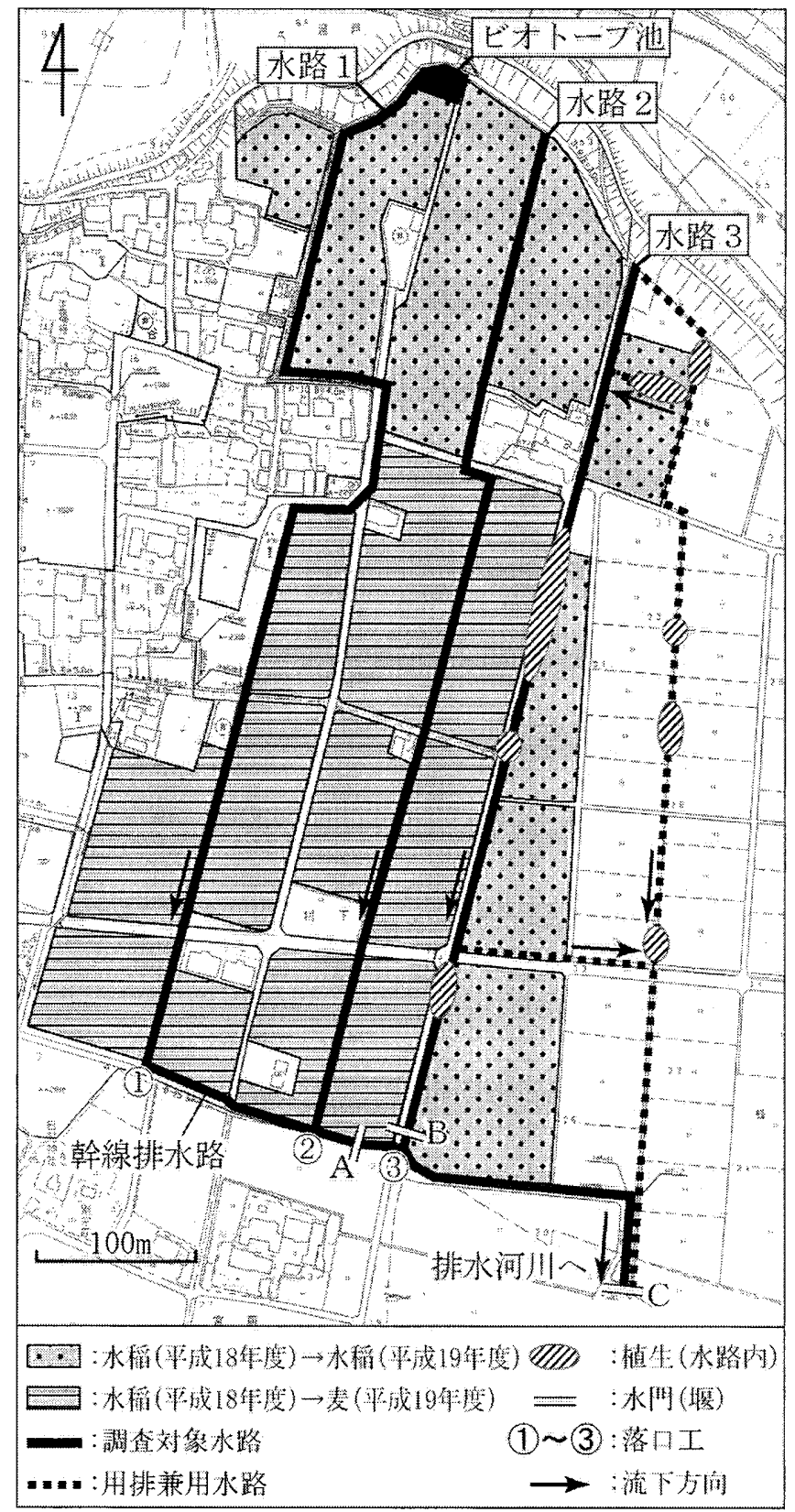

図 1: 調查地区の概要
平成 17 年度の冬期に水田の汎用化を目的として，水 路1及び2とそれに隣接する圃場が整備された。本事業 では，大区画化を目的とした畦畔の撤去および区画整 理，表土扱いを伴う客土，それに暗渠の埋設と排水路 の掘り下げが行われた。

平成 18 年度は, この $2 つ$ 水路の集水域の全水田で水 稲が作付けされ，平成19年度は上流の一部の水田を除 いて畑地転換が行われ，麦（約10.6ha）が作付けされ た。水路3は，30年以上前に整備された水路で，水路内 には砂泥が堆積し，ヨシなどの植生が繁茂している. 整備前は水路1〜3はそれぞれ土砂が堆積して水路内植 生が繁茂している状態であったが，全水路の同時改修 は生態系への影響が大きいことから, 水路3はそのまま の状態で保存された，また，水路3は，水田内の小水路 （用排兼用水路）と接続しており，平成18，19年度と もに周辺圃場は水稲が作付けされていた。調査対象と した3本の排水路は幹線排水路に合流し，さらに水門C を通して，排水河川に流下している。

\section{2 調查方法}

水路内 (水路 1 3) の調査地点は約 $100 \mathrm{~m}$ 間隔で設定し た. 本調査では魚類の生息状況を調査地点ごとではなく, 水路ごとに把握するため, 多くの魚類が生息すると思われ る水路湾曲部や道路下の日陰部分を中心に調査地点を 選定した. 落口工 (1)〜 (3)) では, 図 2 に示すような落口工 の直下流の深み (幅 $1.0 \mathrm{~m} \times$ 長さ $1.0 \mathrm{~m} \times$ 深さ $0.2 \mathrm{~m}$ ) になつ ている地点で調査を行った. 各調査地点では, サデ網 (開 口 $95 \mathrm{~cm}$, 深さ $70 \mathrm{~cm}$, 目合い $2 \mathrm{~mm}$ ) と夕モ網 (開口 $45 \mathrm{~cm}$, 深さ $45 \mathrm{~cm}$, 目合い $2 \mathrm{~mm}$ ) 使用して魚類を採捕し, 種の 同定, 個体数と体長の計測を行った. 採捕の際に追い込 む距離は水路フリュームの 2 アーム分 (約 $1.7 \mathrm{~m}$ ) とし, 2 人 1 組で実施した. ビオトープ池の捕獲調査は, カゴ網（目合 い $2 \mathrm{~mm}$ )を使用したが, 水深が浅い場合には 3 人 1 組に なって採集面積 $4 \mathrm{~m}^{2}$ (幅 $2 \mathrm{~m} \times$ 距離 $2 \mathrm{~m}$ ) をサデ網で追い込 んで捕獲した.なお，追い込多は 1 分間の採集時間で 2 回実施した. 採捕した個体は, 測定後元の箘所に放流し た. 採捕した地点で，水質計（TOADKK製 WQC-24）によ る水質計測と, 水深を測定した. 水質の测定項目は, 水 温, $\mathrm{pH}, \mathrm{DO}, \mathrm{EC}$ の 4 項目である. なお, 無降雨時の排水 路内には水の流れがほとんどないことから流速の測定は 省略した. また, 水路内の植生や堰の有無など水路内の 環境についても記録した。

調査は, 平成 18 年と平成 19 年の 4 月から 12 月までの 各月 1 回(平成 18 年 8 月は欠測), 計 17 回実施した.

また, 水路3では, 魚類が捕獲された地点から最も近い 植生 (水路3と用排兼用水路の水面下における水路内植 生)までの距離を計測した.これにより, 水路内の環境を改 善するために植生帯を配置する際の目安となる間隔につ いて検討した。

\section{3 結果及び考察}

\section{1 水路内の環境}

水路内環境の調査結果を表 2 に示す. 水路内の環境で 最も大きく変化したのは水路 1 及び水路 2 の水深であつ た. 水稲のみが栽培された平成 18 年度は幹線排水路中 に設置された堰 $\mathrm{A}$ (高さ $0.9 \mathrm{~m}$ )における堰上げによって灌 
表 1: 調査対象施設の概要

\begin{tabular}{|c|c|c|c|c|c|c|c|}
\hline & 水路 1 & 水路 2 & 水路 3 & 落口工1 & 落口工(2) & 落口工(3) & ビオトープ汁 \\
\hline 水路整備状況 & 用排分離 & 用排分離 & 用排兼用 & - & - & - & - \\
\hline 水路延長(m) & 780 & 620 & 550 & - & - & - & \multirow{2}{*}{$100 \mathrm{~m}^{2}$ （面積 } \\
\hline 水路幅(m) & $0.6 \sim 0.9$ & $0.6 \sim 0.9$ & 0.6 & 1.0 & 1.0 & 1.0 & \\
\hline 水路の深さ(m) & 0.9 & 0.9 & 0.6 & 1.3 & 1.3 & 1.5 & - \\
\hline 水路勾配 & $1 / 2000$ & $1 / 2000$ & $1 / 2000$ & - & - & - & - \\
\hline 側面 & $\mathrm{Co}^{*}$ & $\mathrm{Co}^{*}$ & $\mathrm{Co}^{*}$ & $\mathrm{Co}^{*}$ & $\mathrm{Co}^{*}$ & $\mathrm{Co}^{*}$ & $\begin{array}{c}\text { ソダ } \\
\text { 石積み }\end{array}$ \\
\hline 底面 & 砂泥/Co ※ & 砂泥/Co & 砂泥/Co * & 礫/Co * & 礫/Co \% & 砂泥/Co * & 石積み \\
\hline 砂泥堆積 $(\mathrm{cm})$ & $0 \sim 5$ & $0 \sim 10$ & $0 \sim 25$ & - & - & $0 \sim 1$ & - \\
\hline \multicolumn{8}{|c|}{ ※Co：コンクリート } \\
\hline 調査地点 & 調査年 & $\begin{array}{l}\text { 水深 } \\
(\mathrm{m})\end{array}$ & $\mathrm{pH}$ & $\begin{array}{c}\mathrm{EC} \\
(\mu \mathrm{S} / \mathrm{cm})\end{array}$ & $\begin{array}{c}\text { DO } \\
(\mathrm{mg} / \mathrm{l})\end{array}$ & $\begin{array}{l}\text { 水温 } \\
\left({ }^{\circ} \mathrm{C}\right)\end{array}$ & 植生 \\
\hline \multirow{2}{*}{ 水路 1} & H18 & $0.04 \sim 1.00$ & $6.0 \sim 7.8$ & $117 \sim 457$ & $0.29 \sim 5.95$ & $9.2 \sim 28.3$ & 畦畔 \\
\hline & H19 & $0.03 \sim 0.29$ & $6.0 \sim 7.6$ & $192 \sim 310$ & $0.53 \sim 4.99$ & $7.9 \sim 27.7$ & なし \\
\hline \multirow{2}{*}{ 水路 2} & H18 & $0.02 \sim 0.92$ & $6.0 \sim 7.3$ & $94 \sim 357$ & $0.20 \sim 5.83$ & $7.9 \sim 31.3$ & 畦畔 \\
\hline & H19 & $0.01 \sim 0.28$ & $6.7 \sim 7.5$ & $197 \sim 340$ & $0.82 \sim 6.05$ & $7.5 \sim 27.4$ & なし \\
\hline \multirow{2}{*}{ 水路 3} & $\mathrm{H} 18$ & $0.03 \sim 0.66$ & $6.4 \sim 7.4$ & $76 \sim 296$ & $0.56 \sim 6.50$ & $8.6 \sim 31.8$ & 畦畔, 水路内 \\
\hline & H19 & $0.01 \sim 0.67$ & $6.8 \sim 7.9$ & $154 \sim 255$ & $0.68 \sim 5.89$ & $7.1 \sim 31.9$ & 畦畔, 水路内 \\
\hline 落口工(1) & H19 & $0.21 \sim 0.34$ & $6.8 \sim 7.7$ & $307 \sim 317$ & $2.69 \sim 5.83$ & $8.3 \sim 27.0$ & なし \\
\hline 落口工(2) & H19 & $0.15 \sim 0.31$ & $6.7 \sim 7.5$ & $271 \sim 300$ & $3.57 \sim 5.25$ & $11.5 \sim 26.5$ & なし \\
\hline 落口工(3) & H19 & $0.12 \sim 0.29$ & $6.8 \sim 7.9$ & $302 \sim 304$ & $3.38 \sim 5.38$ & $8.7 \sim 27.9$ & なし \\
\hline ビオトープ池 & $\mathrm{H} 19$ & $0.15 \sim 0.83$ & $7.0 \sim 7.9$ & $190 \sim 277$ & $4.25 \sim 6.86$ & $12.0 \sim 28.0$ & 池岸 \\
\hline
\end{tabular}

溉期の水深が $90 \mathrm{~cm}$ を上回り，排水路内の水深が側壁を 超えて畦畔まで上昇していた。 その結果, 水路内には植 生は無かったものの, 畦畔植生が水没して水際に植生が 生じていた.このような排水路水位の確保は, 水田からの 漏水を防ぐことを目的としている. 一方, 平成 19 年度は水 路下流側の圑場で麦の転作が導入されたため, 転作圃場 内の地下水位低下を目的として排水路水位が下げられ た. 魚類保全に配慮して高さ約 $14 \mathrm{~cm}$ の堰板が排水路内 に約 $30 \mathrm{~m}$ 間隔で設置され水深の維持が図られたが，排水 路内の水深は暗渠管出口を塞がないように最大でも $30 \mathrm{~cm}$ を越えないように管理されており, 前年度のように畦畔の 植生が水没することは無く, 水際植生は確認されなかっ た. 水路 3 では, 水門 B (高さ $0.65 \mathrm{~m}$ )によって灌溉期の水 深は $60 \mathrm{~cm}$ 前後で維持され, 水面が畦畔植生まで達する だけでなく, 水路内にも植生が繁茂していた。また,地区 外に集水域を持つ幹線排水路の水位は両年度を通じて 変化が少なかった.

水質については，転作時における暗渠排水の影響が予 想されたが, 大きな変化は認められなかった. 落口工地点 及びビオトープ池で DO の最小值が水路内よりも高い值を 示している. 落口工地点では水路との落差によって常に水 が撹找される状態であったこと,ビオトープ池では揚水機 場の大型ポンプで取水した農業用水が流入していることが 影響し，DO の最小值が高い值で維持したと考えられる。 また, 水路内の DO 值は無降雨時の水の流れが少ない時
期に低くなる傾向が見られた。一方, EC は排水路水深の 小さい中干し期や落水後の $11 \sim 12$ 月にかけて高い值を 示す傾向が見られた.これは, 灌溉期は, 水路底質や生 活排水の影響を農業用水によって希釈していたためと考 えられる. 落口工(1)〜 (3)の3 地点では水路改修により図 2 に示すような落差が生じている. それぞれの落差(下流側 水面から上流側水路底までの標高差) は, 降雨や落水の 影響の無い平常時において, 落口工(1)で $0.27 \mathrm{~m}$, 落口工 (2)で $0.33 \mathrm{~m}$, 落口工(3)で $0.55 \mathrm{~m}$ となっており, 幹線水路か ら各水路への魚類の遡上が困難であると考えられる.

以上のことから，汎用化水田に麦作を導入したことによる 影響は, 排水路水深の低下及びそれに伴う水路内植生の 消失であり, 水質はほとんど変化しないことが示めさ

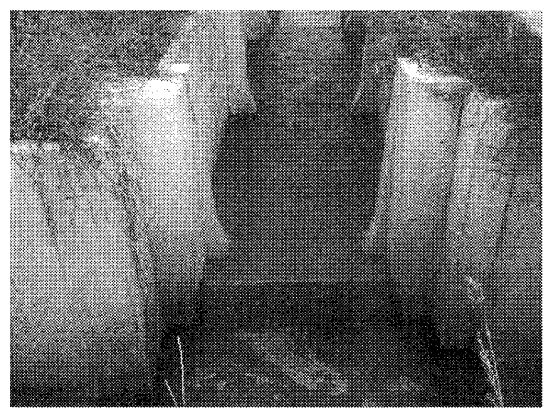

図 2: 落口エ(1)の落差 
表 3: 採捕結果

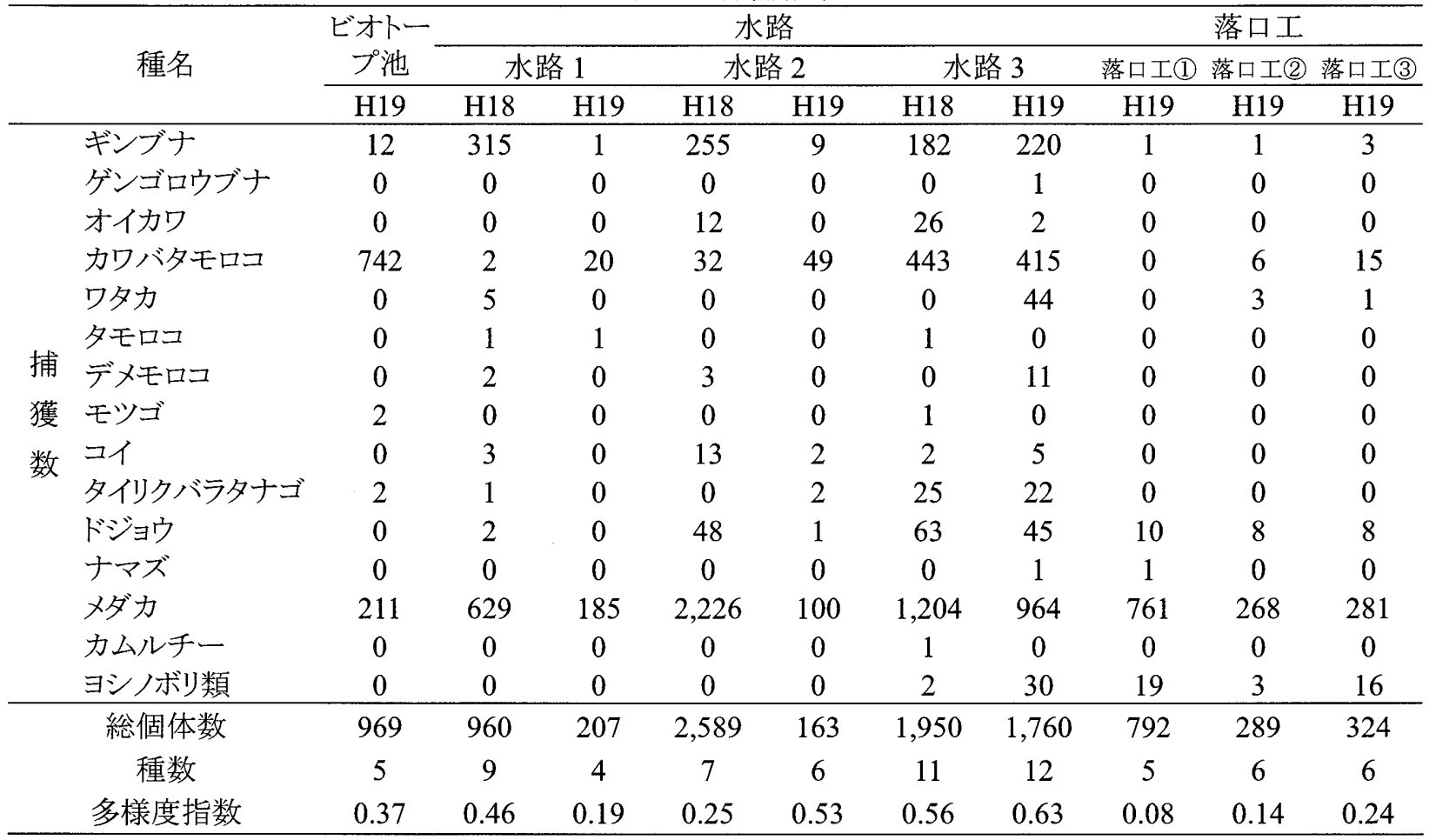

れた. また，改修によって生じた落口工における水路間の 落差は, 魚類の移動に支障をきたすと考えられるため, 簡 易的な魚道を設置するなど何らかの詨策が必要である.

\section{2 魚類の生息状況}

各調査地点における魚類の調査結果を表3に示す. 表中 の捕獲数とは, 平成 18 年度は8回, 平成19年度は9回の調 査における総捕獲数である. なお, ビオトープ池及び落口 工(1)〜 (3)は, 平成18年度の水稲収穫後に改修が行われ たため, 平成19年度から調査を開始した. また, 調查結果 から (1) 式で表わされるSimpsonの多様度指数 $D$ （宮下. 野田, 2003)を表3に示した。

$$
D=1-\sum_{i=1}^{S} P_{i}^{2}
$$

ここに, $S$ は群集に含まれる種の数, $P_{i}$ は種 $i$ の個体数が 群集の全個体数に占める割合である.

各水路等における魚類の多様性について Simpson の 多様度指数からのその大まかな傾向を検討する.まず, 用 排兼用水路と連続し灌溉期の水深が大きい未整備の水路 3 では, 平成 18 年度および平成 19 年度ともに 0.56 以上 の大きな值を示した.これに対して, 汎用農地として固場 整備が完了した整備済みの水路 1 と 2 についは, いず れも水路 3 より低い值を示した. 水路 1 は種数と捕獲数が 減少し, 多様度指数も 0.46 から 0.19 にまで低下している. 水路 2 については, 種数や捕獲数は減少しているが, 多 様度指数は平成 19 年度の方が高い值を示している.これ は, メダカの捕獲数が大幅に減少したために, 多様度指 数の算定時にメダカの捕獲数による影響が小さくなり多様 度指数が大きくなったといえる. 落口工(1)〜 (3)は水面積 $1 \mathrm{~m}^{2}$ と生息空間が限定されていることもあり, 水路 1 ～3 の 多様度指数に比べてかなり低い数值を示しているが，水 路 3 の下流端に位置する落口工(3)の多様度指数は, 水路

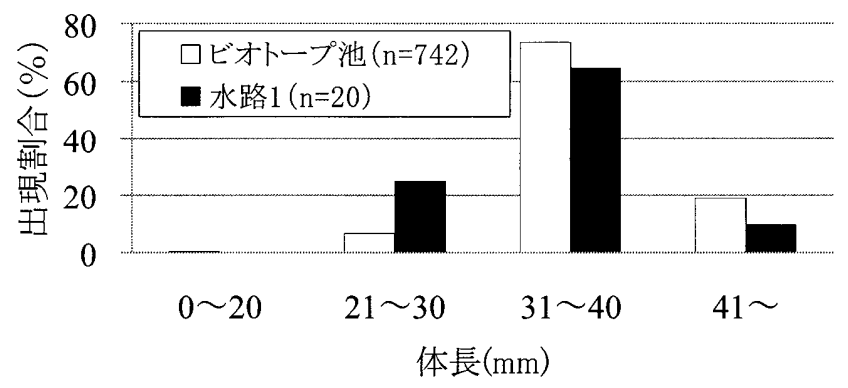

図 3: ビオトープ池と水路 1 におけるカワバタモロコの 体長分布 (平成 19 年度)

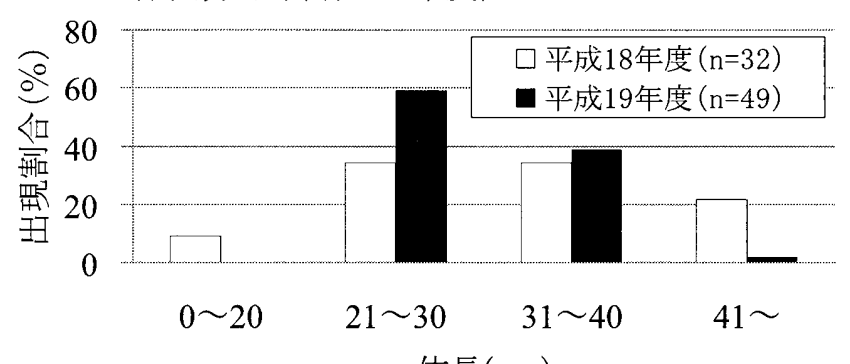

体長 $(\mathrm{mm})$

図 4:水路 2 におけるカワバタモロコの体長分布

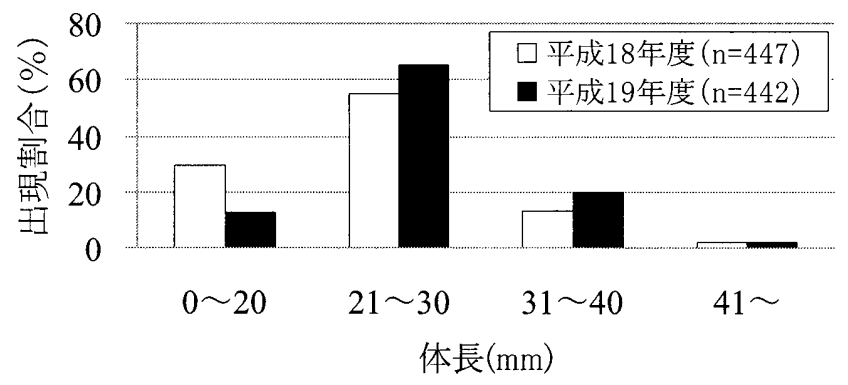

図 5 : 水路 3 におけるカワバタモロコの体長分布 
1 および2の下流端にある落口工(1)と(2)の值に比べて大き く, 合流寸る排水路の影響を強く受けている. 次に, この地 域で捕獲された各魚種の傾向について述べる. 水路 1 及 び水路 2 では, 平成 18 年度から平成 19 年度にかけて力 ワバタモロコが増加したが，その他の多くの魚種の捕獲数 は著しく減少している. とくにメダカやギンブナでその傾向 が顕著である.一方, 水路 3 ではドジョウの捕獲数が減少 していたが，その他の魚種は，増減の変化が少ないか，あ るいは増加していることから, 水路 3 における魚類の生息 環境は安定していたと考えられる.

平成 18 年度の冬期に水路 1 の上流端に新設されたビ オトープ池は, 捕獲された種数は少ないものの, メダカとカ ワバタモロコが多数生息していた. とくに，平成 19 年度に 捕獲したカワバタモロコの総数は742 個体と極めて多く, ま た，図 3 の体長分布図に示すように，3 個体(総捕獲数の $0.4 \%$ ) の仔稚魚 (体長 $20 \mathrm{~mm}$ 以下を仔稚魚とする)を確認 し, ビオトープ池内で繁殖している可能性が示唆された. ビオトープ池と連続している水路 1 におけるカワバタモロコ の捕獲数は, 平成 18 年度の 2 個体から平成 19 年度の 20 個体に増加したものの, 図 3 に示すように, 仔稚魚が全く 確認されなかった.これより,ビオトープ池で繁殖した個体 が流下したことによって水路 1 内の成魚の捕獲数は増加し たが, 仔稚魚は捕獲されなかったことから, 水路 1 内で繁 殖できなかったと考えられる. また, 水路 2 では, 図 4 に示 すように, 平成 18 年度に捕獲したカワバタモロコは 32 個体 でそのうち仔稚魚 3 個体 $(9.4 \%)$ を確認し, 水路 2 内で繁 殖した可能性が示唆された. しかし，排水路の水深が低下 した平成 19 年度に捕獲数が 49 個体と若干増加したもの の仔稚魚が全く確認されず, 繁殖できない環境に変化し たと考えられる. 一方, 常時水際に植生が存在した水路 3 ではカワバタモロコの捕獲数が多い. 図 5 に示すように, 平成 18 年度は総捕獲数 443 個体のうち仔稚魚が 133 個 体 $(29.8 \%)$, 平成 19 年度は総捕獲数 415 個体のうち仔稚 魚が 54 個体 $(12.8 \%)$ で, 両年度とも水路内での繁殖を確 認した.すなわち,ビオトープ池および水路 3 がこれに連 結する水路系の力ワバタモロコの保全に大きな役割を果た していることが示された。

ビオトープ池におけるメダカの体長分布（図 6)を見ると, 体長 $20 \mathrm{~mm}$ (卯孚化後 3 力月程度)未満の仔稚魚は総捕獲 数の約 $37 \%$ を占め, ビオトープ池内で繁殖していることが 示された. 水路 2 における平成 18 年度から 19 年度にかけ てのメダ力の体長分布の変化(図 8)より, 平成 18 年度は 体長 $20 \mathrm{~mm}$ 未満の仔稚魚が総個体数の $38 \%$ 占め繁殖 が確認できたが, 平成 19 年度には体長分布のピークが右 側に移行したものの $20 \mathrm{~mm}$ 未満の仔稚魚がほとんど確認 できなかった。すなわち, 平成 19 年度のメダ力は, 平成 18 年度に餒化した個体が成長したもので, 平成 19 年度は繁 殖しなかったと考えられる。これは，平成 19 年度は水田 に麦作を導入し水路内の水深が低下したことによって, 水 路内の植生として機能していた畦畔植生まで水面が上昇 せず，繁殖環境がなくなったことが仔稚魚をほとんど確認 できない原因と考えられる。，一方，水路 1 は，水路 2 と同様 平成 19 年度に麦作が導入され排水路水位が低下し, メダ 力の繁殖環境が消失されたことが予想された.しかし，図 7 の体長分布図加平成 19 年度も体長 $20 \mathrm{~mm}$ 末満の仔稚 魚が相当数確認された.これは, 水路 1 の上流のビオトー プ池で繁殖した仔稚魚が流下したことによるものと思われ る.なお，図 9 からも分かるように，平成 18 年度と 19 年度

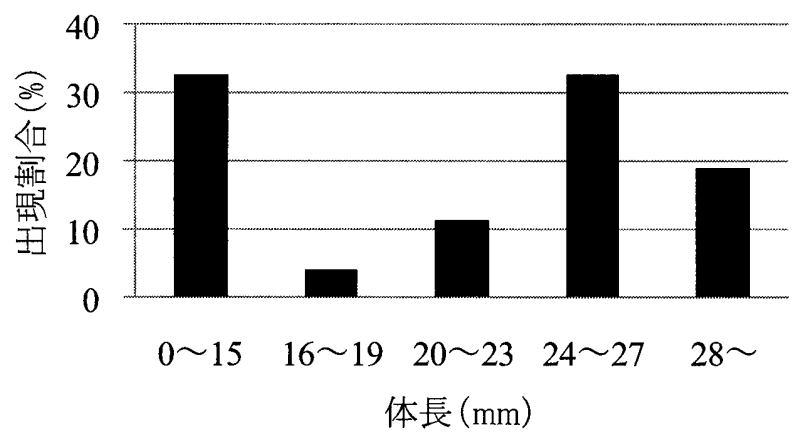

図 6:ビオトープ池におけるメダカの体長分布 (平成 19 年度: $\mathrm{n}=201$ )

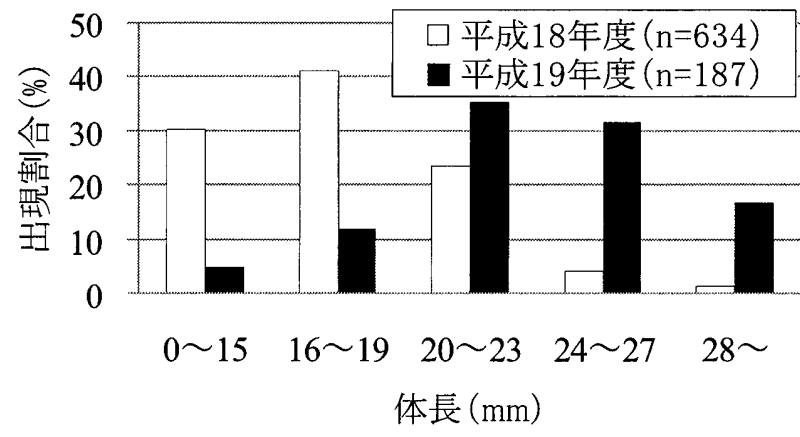

図 $7:$ 水路 1 におけるメダカの体長分布

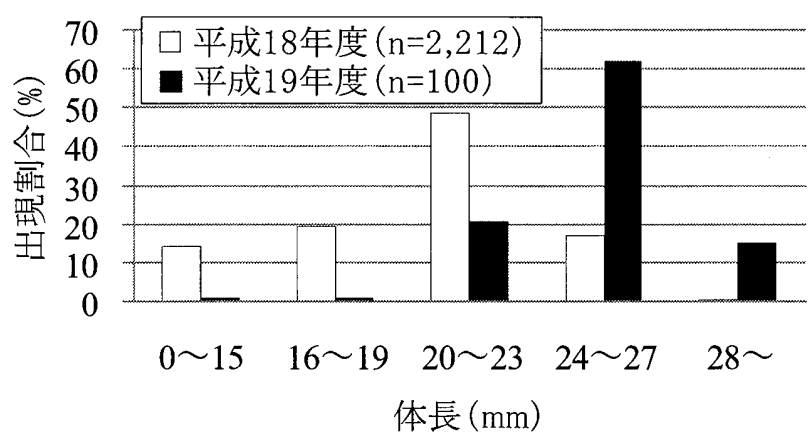

図 8:水路 2 におけるメダカの体長分布

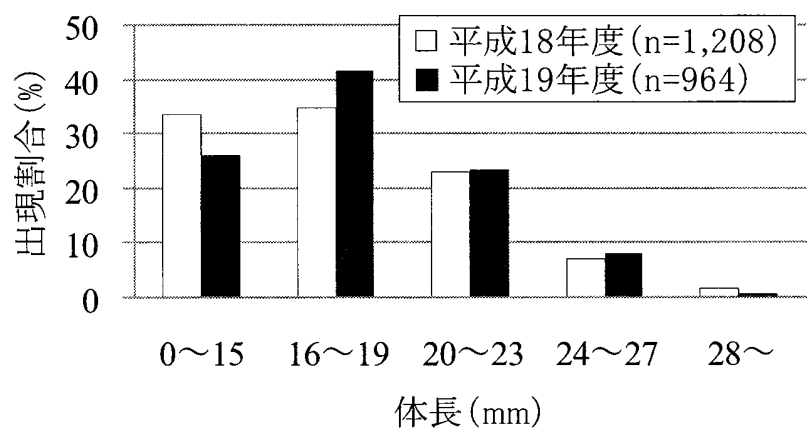

図 9:水路 3 におけるメダカの体長分布

とも灌溉期の排水路水位が高く管理された水路 3 では, 両 年度の体長分布に大きな傾向の変化はなく，この水路内 でメダカの繁殖と生育が安定的に繰り返されていることが 示されている. 
平成 18 年 5 月には, 日雨量 $100 \mathrm{~mm}$ を超える降雨が観 測されている.この降雨時に水路 1 及び 2 において, ギン ブナが遡上するのを目視で確認している. その後, 多数の ギンブナの仔稚魚が捕獲されるようになった. しかし, 平成 19 年度には, 遡上個体も繁殖個体も確認することはできな かった.この原因として, 通常の降雨時には排水路水位が 上昇しても水路内の落差が解消されず遡上できなかった こと, 水路内に産卵床となる植生がなかったことなどが考え られる. また, 水路 1 と水路 2 における魚類の調査結果 から, 平成 18 年度に繁殖した仔稚魚は, 降雨時に落口 工より下流へ流下し, 水路内で越冬しなかったと推定され る. 一方, 水路 3 の捕獲数はほとんど変化しておらず, ギ ンブナは水路内で定着していた.これより, 水路内で繁殖 や生息できる環境が必要となるだけではなく, 水路内の落 差部に水路魚道を設けること, さらに, 水路の一部に遊泳 力の乏しい魚種や仔稚魚が生息できる区間を設け，そこ が越冬地として機能するよう水深の確保に配慮できれば, ギンブナの繁殖も可能になると考えられる.これは, 類似し た生活史を有するオイカワやコイについても同様のことが 言える.

以上のことから, 水路内の魚類が減少した要因は, 水深 が低下したことによって畦畔植生が生息場所として利用で きなくなったこと, 下流部に遡上が困難な落差の発生, お よび定着・越冬の拠点となるような場所の久如にあるといえ る. とくに水路内の植生は, 産卵床となるだけでなく, 植生 の内部は流速が低下し遊泳能力の低い仔稚魚の隠れ場 となるため, 上記の問題点の解決には非常に重要である. また, 植生に付着した藻類などが慨となるなど多面的な役 割を果たしている。

\section{4 ミティゲーションの検討}

捕獲調査の結果から, 水路内の環境要素として, 植生の 有無が重要であることがわかった. そこで, 水路 1 と水路 2 にも植生帯を設けることが望ましいと判断し, 平成 19 年 4 月に U 字工をトンネル状になるよう水路内に伏せて置き, その上にアヤメなどを植栽したプランタ一を設置した. 水 路底面からプランター上部まで約 $0.4 \mathrm{~m}$ の高低差がある. この対策は, 水路内に隠れ場 (U 字溝下)や植生 (プランタ 一内)を提供するために工夫したものである.しかし, 環境 調查の結果から, 麦作が導入された平成 19 年度の場合, 排水路の水深が $0.3 \mathrm{~m}$ 以下になるように管理されたことか ら, プランターまで水面が達せずプランター内の植生が魚 類の繁殖や生息環境としての役割を果たさなかった.ま た,このプランターを 10〜20m 程度の間隔で配置したが， どの程度の間隔が適当であるかの基準も明らかでなかつ た.

そこで, 水路内に植生が繁茂し, 魚類の生息に適した 環境であると思われる水路 3 の水域において, 調査地点 の魚類の捕獲数と, 上下流に関係なく最も近い植生まで の距離との関係を明らかにすることによって, 植生を配置 する際の間隔について検討した (図 10). 魚類の捕獲数は 平成 19 年度のものを, 植生の位置は水路 3 とそれに接続 している用排兼用水路のものを使用した. 調查対象とした のは汎用化水路でも多く確認されたメダカ，カワバタモロ コ, ギンブナの 3 種である.

図 1 に示すように, 水路 3 とそれに接続した用排兼用水路 の水路底には砂泥が厚く堆積し, 水路内の各所に植生が分布 していた．水路内に繁茂している植生は，ギョウギシバやヨ

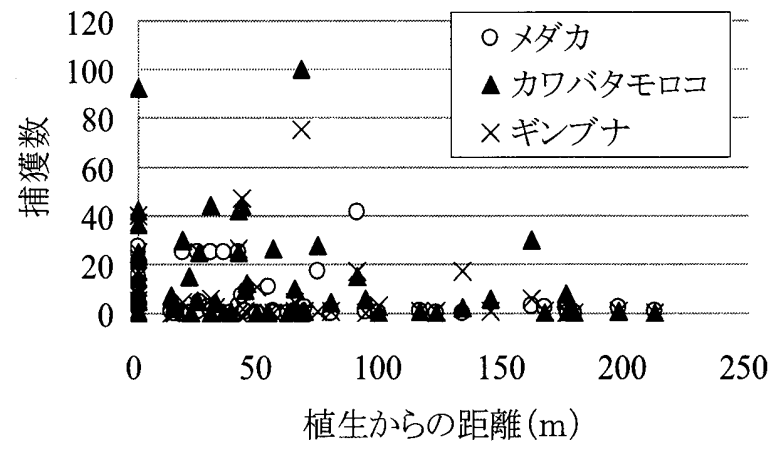

図 10: 植生までの距離と捕獲数の関係

シ・メヒシバといったイネ科の植物やイヌタデやミゾ ソバといったタデ科の植物, ヒメクグやタマガヤツリ といったカヤツリグサ科の植物が多く確認された.

魚類の生息は植生以外の要因によっても影響されるの で, 個体数は植生からの距離にしたがって単純に減少す るような関係は見られなかった.しかし，3 種の魚類とも植 生からの距離が $100 \mathrm{~m}$ を超えると捕獲数が減少する傾向が みられる. 以上のことから, 今回対象とした魚類について は, 水路内植生をおおよそ $100 \mathrm{~m}$ 間隔で設置すれば, 生 育環境が連続すると思われる.

\section{5 まとめ}

調査の結果, 整備された沉用化水田に麦などの畑作物が 栽培されることによって排水路の水深が低く管理されること が明らかになった。このことによって, 水路内の植生環境 が大きく変わり魚類の生息に大きな影響を与えていること がわかった.よって, 水深が変化しても対応できるような環 境を水路内に創出する必要がある.

植生帯の有無が魚類の生息に大きな影響を与えてお り,この植生配置の際の基準となる適正な間隔を示すこと ができた.今後, 他の環境下でも多種の魚種について同 様の検討を行うことが望まれる. また, 植生帯を設ける際に 移植する植物種や工法についても検討することが必要で あろう。

調査の結果，魚類の移動障害となっている落口工の 落差も明らかになった。 その落差の直下流の深みは中 干しなど急な落水があった際の魚類の避難場所の役割 を果たしている可能性が示唆されたため，この落差に 水路魚道を設ける場合には, 深みをなくすのではなく, 深みを有効に活用できる魚道の設置が望ましいと考え られた。

本研究を行った地域では, 周辺住民の環境への関心が 高く, 堰板の設置など住民の理解が大きい. 地域の環境 を保全していくためには，地域住民の理解と協力が不可 欠である.今後は, 地域生態系の保全方法だけでなく地 域住民の協力が得られるような手法を模索していかなけれ ばならない。

\section{引用文献}

[1]宮下 直·野田隆史(2003): 「種多様性」『群集生態学』, 東 京大学出版会, pp.73-105.

[2] 小澤祥司(1999): 生きもの豊かな水田を再び, 水情報， 19(4), pp.8-11. 
[3]上月康則・佐良陽一・村上仁士・西岡健太郎・倉田健悟・ 佐藤家康・福田守(2000):都市近郊用水路網におけるメダ カの生息環境要因に関する研究, 環境システム研究, 28 , pp.313-320.
[4]農林水産省農村振興局計画部事業計画課 (2004): 環境 との調和に配慮した事業実施のための調査計画・設計の 手引き 3 -ほ場整備 (水田・畑) 一, 農業土木学会, p.4-19.

この論文の公開の質疑または討議は2012年12月31日 まで受付けます。 